\title{
On-Farm Assessment of Maize Storage and Conservation Technologies in the Central and Northern Republic of Benin
}

\author{
Evelyne Sissinto Gbenou ${ }^{1, *}$, Ygué Patrice Adégbola ${ }^{2}$, Pélagie Manhoussi Hessavi ${ }^{3}$, \\ Segla Roch Cedrique Zossou ${ }^{3}$ and Gauthier Biaou ${ }^{4}$ \\ 1 Departement of Economics, Socio-Anthropology and Communication for Rural Development, \\ University of Abomey-Calavi, Abomey-Calavi 01 BP 526, Benin \\ 2 Agricultural Policy Analysis Program, National Institute of Agricultural Research of Benin, \\ Cotonou 01 BP 884, Benin; patrice.adegbola@yahoo.fr \\ 3 International Center of Research and Training in Social Science, Porto-Novo 02 BP 238, Benin; \\ hess.pelagie@gmail.com (P.M.H.); rochybuggs@yahoo.fr (S.R.C.Z.) \\ 4 Rectorate, National University of Agriculture, Porto-Novo 01 BP 55, Benin; gbiaou@yahoo.fr \\ * Correspondence: evesinto@yahoo.fr; Tel.: +229-97-05-27-74 or +229-95-96-28-57
}

\section{check for} updates

Citation: Sissinto Gbenou, E.; Adégbola, Y.P.; Hessavi, M.P.; Zossou, S.R.C.; Biaou, G. On-Farm Assessment of Maize Storage and Conservation Technologies in the Central and Northern Republic of Benin. Agriculture 2021, 11, 32. https://doi.org/10.3390/ agriculture11010032

Received: 6 November 2020 Accepted: 16 December 2020 Published: 5 January 2021

Publisher's Note: MDPI stays neutral with regard to jurisdictional clai$\mathrm{ms}$ in published maps and institutional affiliations.

Copyright: (C) 2021 by the authors. Licensee MDPI, Basel, Switzerland. This article is an open access article distributed under the terms and conditions of the Creative Commons Attribution (CC BY) license (https:// creativecommons.org/licenses/by/ $4.0 /)$.

\begin{abstract}
The loss rates and financial profitability of maize storage and conservation technologies were assessed in the central and northern regions of the Republic of Benin. The experimentations were conducted specifically in the villages of Boukoumbé and Savalou and were randomly sampled. A total of four storage technologies were offered to 137 producers: the polypropylene bag, the Purdue Improved Cowpea Storage (PICS) bag, the metal silo, and the improved and closed earthen attic (with or without stock processing). The method by Pantenius was used to determine the loss rates, and the economic method of Gittinger was used to evaluate the profitability of technologies. The results showed that the technologies that recorded fewer losses in the two communes during storage were the PICS bag with grain treatment by chemical conservation measures in Savalou (9.42 $\pm 4.64 \%)$ and Boukoumbé ( $2.69 \pm 0.77 \%)$, the PICS bag without grain treatment in Savalou (11.71 $\pm 2.78 \%$ ), the metal silo with grain treatment in Boukoumbé $(4.92 \pm 1.36 \%)$ and the polypropylene bag with grain treatment in Savalou (10.56 $\pm 2.80 \%)$ and Boukoumbé (4.02 $\pm 1.23 \%)$. Therefore, the financial analysis results indicated that the most profitable storage technologies were the PICS bag with treatment in the center of Benin and the polypropylene bag without treatment in northern Benin.
\end{abstract}

Keywords: maize; storage systems; financial profitability

\section{Introduction}

Maize cultivation occupies almost $70 \%$ of the total area devoted to cereals in Benin. The area sown for maize production was 1,003,715 ha in 2016 across the country, representing the production of 1,300,000 tons of maize MAEP [1]. Crop covers 53 municipalities out of the 77 municipalities in Benin and is present in the seven Agricultural Development Hubs (ADHs). In Benin, maize is the staple food and the only cereal that generates exportable surpluses to neighboring countries, namely, Niger and Nigeria Sohinto et Aïna [2].

Efforts have been made over the past 10 years to increase the production of maize by improving productivity and subsidizing seeds through several projects, including the West Africa Agricultural Productivity Program (WAAPP), as well as technical and financial partner projects. Efforts to increase the production of maize have also included the provision of fertilizers and herbicides. Adégbola [3] analyzed the impact of the adoption of improved varieties of maize and concluded that this practice increased the yield by $9.77 \mathrm{~kg} / \mathrm{ha}$. Thus, the adoption of improved varieties of maize improved the income from production by 2427 FCFA per hectare. In the distribution of maize production costs, labor is the highest variable cost item in all maize production systems in Benin. The supply of foodstuffs, such as maize, to the population, presents a temporal and spatial gap between production and consumption. This gap is filled by the storage of maize. 
During this storage stage, maize stocks suffer losses that reduce the potential quantity of the food and lead to a reduction in agricultural income. To mitigate the magnitude of the losses and to allow producers to have a relatively large marketable surplus, improved maize storage and conservation technologies were introduced from 1996 to 2004 Fandohan, Maboudou [4,5]. Despite advances in research in the implementation of innovations that can significantly reduce these loss rates, it has been found that the adoption of these new techniques has not been effective among many producers who prefer to continue their endogenous practices Maboudou [6]. Storage losses lead to losses of seeds, fertilizers, pesticides and labor during the production of stored maize, and significant postharvest losses will reduce farm income.

Adégbola [7] showed that the use of improved storage technologies provided a significantly higher income than previous or endogenous local technologies. These technologies allowed adoptive producers to acquire more material than nonadopters. Additionally, the adoption of these improved technologies contributed to the improvement of production factors (land, capital, labor). Previous research has shown that the adoption of improved maize storage technologies had a positive impact on income and hence on the acquisition of material goods and investments in human capital and production. Based on the analysis of Hinnou and Aloukoutou [8], it appeared that the financial means, the difficulty of construction, the risks of intoxication (due to the smell of sofagrain after several months of storage), the positive impact of accessibility to building materials of granaries and the positive impact of the mastery of construction techniques were the main issues affecting the adoption of these improved technologies. Hinnou and Aloukoutou [8] concluded that in the North, it was necessary to promote storage in bags with non-winnowing after ginning and the use of the repellent leaves in clay granaries. In contrast, in the South, improved granaries made of plant materials with repellent leaves, especially neem, and bags of grain maize with "Phostoxin" were the best possible alternatives. Jones et al. [9] evaluated the storage of maize grains with the use of sofagrain and in Purdue Improved Cowpea Storage (PICS) bags without chemical conservation measures and determined that the weight losses were only $0.5 \%$ without the use of chemicals in PICS bags. They concluded that the PICS bag had a good chance of adoption in Ghana, Tanzania, Kenya, Malawi and Mozambique, where tests have been carried out.

Over the past ten years, with the LISA projects of the NGO Louvain Cooperation and the Postharvest Project of HELVETAS Swiss Intercooperation, storage technologies have been developed and introduced in rural areas in central and northern Benin. The following storage technologies have been tested in Benin and compared to the existing technology used by producers: the polypropylene storage bag ZeroFly ${ }^{\circledR}$, the metal silo and the PICS bag. The polypropylene bag is one of the most used materials by producers in Benin for storing maize. This technology can be classified as "peasant know-how". The situation is the same for earthen granaries, which have been improved over time. Maize stored in polypropylene bags with or without treatment undergoes postharvest losses ranging between $3.66 \%$ and $13.21 \%$ Sissinto-Gbénou [10]. Recently, several studies have highlighted the effectiveness of hermetic storage technologies for reducing losses of maize stored in Benin and in its subregions [11-15]. In addition, the socioeconomic aspects of storage technologies were partially addressed by Adégbola [7] and Adéoti et al. [16]. Therefore, the objective of this research was to evaluate the storage losses and profitability of improved maize storage technologies in central and northern Benin. Financial profitability is an important criterion for producers as economic agents and will allow them to decide whether to adopt these technologies. The method of Pantenius [17] was used for loss rates, and the economic method of Gittinger [18] was used to assess the profitability of different maize storage and conservation technologies. 


\section{Materials and Methods}

\subsection{Experimentation Sites}

The experiment was carried out in the municipalities of Savalou and Boukoumbe in the central and northern regions of Benin, respectively. The municipality of Savalou is located in the savannah-humid agroecological zone $(800-1000 \mathrm{~mm})$, and that of Boukoumbé is located in northern Benin in the humid agroecological zone (>1000 mm). Boukoumbé is between $10^{\circ}$ and $10^{\circ} 40^{\prime} \mathrm{N}$ latitude and $0^{\circ} 75^{\prime}$ and $1^{\circ} 30^{\prime} \mathrm{E}$ longitude with an annual average rainfall of $1067 \mathrm{~mm}$ and average temperature of approximately $27^{\circ} \mathrm{C}$, with variations from 20 to $38{ }^{\circ} \mathrm{C}$ Tchegnon [14]. In Savalou, the average annual rainfall is $1150 \mathrm{~mm}$, with annual variations between 864 and $1637.3 \mathrm{~mm}$, and temperatures are high throughout the year, with minimums between 23 and $24{ }^{\circ} \mathrm{C}$ and maximums between 35 and $36{ }^{\circ} \mathrm{C}$ [19]. Four and ten villages were selected in Savalou and Boukoumbé, respectively, based on the production level and the importance of maize in the production system. The experiments were carried out over three years. In the first year, 23 and 27 farmers were selected in Savalou and Boukoumbé, respectively, based on their willingness to host and ability to manage the experimental storage trials. To perform analyses, we used data from farmers who participated in the trials for two successive years, either the first and second years or the second and third years. This gave rise to a total of 12 producers in central Benin (Savalou) and 13 in northern Benin (Boukoumbé).

\subsection{Storage Technologies}

Four types of storage structures were used to store maize grains during the experiments: (1) Polypropylene bags with a capacity of $100 \mathrm{~kg}$; (2) Purdue Improved Crop Storage (PICS) bags with a capacity of $100 \mathrm{~kg}$; (3) Improved clay granaries of different capacities, the largest of which was $1000 \mathrm{~kg}$; (4) Metal silos with a capacity varying from 250 to $1000 \mathrm{~kg}$. Generally, in both study areas, farmers had been using improved clay granaries and polypropylene bags for grain storage Sissinto-Gbénou [10]. However, as the polypropylene bag was a widely used storage structure, it was considered as the control structure in the experiment. The other storage structures offered alternatives to producers. The polypropylene bag and the improved clay granary were storage technologies that already exist in rural areas. The PICS bag was developed by Purdue University and has been more commonly used to store cowpea than maize. Both the large metal silo and PICS bag were introduced in Benin for product storage at a community level. In this study, we used silos for agricultural product storage at an individual producer level.

In addition, maize was treated using Actellic ${ }^{\circledR}$ Super powder (2\% pirimiphos-methyl) to protect the stocks of maize against pest attacks. The insecticide was applied at a rate of $50 \mathrm{~g}$ Actellic ${ }^{\circledR}$ Super powder per $100 \mathrm{~kg}$ maize grains. This insecticide is recommended by the Plant Protection and Phytosanitary Control Service to farmers in the Republic of Benin. It is an easily biodegradable insecticide that is only slightly persistent. Actellic ${ }^{\circledR}$ Super is effective in combating Sitophilus zeamaïs, but is ineffective against borers (Bostrichidae), including the grain borer (Prostephanus truncatus). It is sold under the trade name of Actellic ${ }^{\circledR}$ Super.

\subsection{Vegetal Material}

The grains of the improved maize variety DMR were used for the experiments in both areas. They were provided by the farmers involved in the experimental trials. The grains had been sorted and dried before storage. The grain moisture levels were recorded at the beginning of the trials.

\subsection{Experimental Setup and Treatments Implemented}

Height treatments were designed for the experiments. Each treatment was a combination of one storage structure, with and without the application of Actellic ${ }^{\circledR}$ Super powder. The experiment was arranged in a completely randomized block design, with a $2 * 4$ factorial experiment for the first year of experiments and a $2 * 5$ factorial experiment 
for the last two years, including the metal silo in the trials. In addition, the principle of divided plots (split-plot) was used. The experience plan was unbalanced because the treatments did not have the same number of repetitions. Two categories of experimental farmers were defined depending on the application of Actellic ${ }^{\circledR}$ Super powder to protect the stocks of maize against pest attacks. The treatments were as follows:

- Treatment 1: Untreated maize grains stored in a polypropylene bag;

- Treatment 2: Untreated maize grains stored in a PICS bag;

- Treatment 3: Untreated maize grains stored in an improved clay granary;

- Treatment 4: Untreated maize grains stored in a metal silo;

- Treatment 5: Maize grains treated with Actellic ${ }^{\circledR}$ Super in a polypropylene bag;

- Treatment 6: Maize grains treated with Actellic ${ }^{\circledR}$ Super and stored in a PICS bag;

- $\quad$ Treatment 7: Maize grains treated with Actellic ${ }^{\circledR}$ Super and stored in an improved clay granary;

- $\quad$ Treatment 8: Maize grains treated with Actellic ${ }^{\circledR}$ Super and stored in a metal silo.

\subsection{Sampling and Data Collection}

During the three experiments years, technical and economic data were collected each year at monthly intervals for seven months, from the establishment of the experiments to the maize destocking. Data collection covered the period from February or March to August or September each year. This period coincided with the seven or eight months of maize storage each year. Each month, four samples of $750 \mathrm{~g}$ per treatment (one per treatment) were taken from each experimental producer for damage and loss evaluation of the storage treatments in the laboratory. A one-meter handle ladle was used to take samples by mixing the grains in the stock enclosure before the sample was taken. Each sample was then saved in an envelope, which was packed in a labeled plastic bag and sealed. The samples were then transported to the laboratory of the Agricultural and Food Technology Program (PTAA) of the National Institute of Agricultural Research of Benin (INRAB) in PortoNovo for further analysis. In the laboratory, the samples were stored in a refrigerator at a temperature of $4{ }^{\circ} \mathrm{C}$ for the two weeks required for the loss rate assessment.

Data on maize storage costs (from harvest to storage) were collected from each trial participant. They included the cost of construction or purchase price of the storage structures, the cost of labor related to maize storage operations (including dispatching and shelling costs), and the cost of the chemical for storing the maize in the structures. Selling prices per kilogram of maize were collected per month for the duration of the experiments at the level of each participant. The interest rates charged by the microfinance institutions (10\% and $12 \%$, in Savalou and Boukoumbé, respectively) and the lifespan of the storage structures ( 1 year for the polypropylene bag, 2 years for the PICS bag, 20 years for the metal silo and 15 years for the improved granary) were considered for the calculation of storage costs. A structured questionnaire was designed to collect these data. The results of the evaluation of the loss rates were used to calculate the amount of financial loss for each storage treatment.

\subsection{Data Analysis}

\subsubsection{Loss Rate}

Several approaches for determining quantitative losses have been developed. The counting and weighing methods were used to assess the rates of maize loss during storage. This method is the most used in studies and produces better results.

The formula used by Pantenius [17] is as follows:

$$
\% \text { Losses }=\frac{(E * B)-(C * D)}{(E * A)} * 100
$$

where $A$ is the total number of grains, $B$ is the number of damaged grains, $C$ is the number of healthy grains, $D$ is the weight of damaged grains and $\mathrm{E}$ is the weight of healthy grains. 


\subsubsection{Storage Costs}

The cost of the maize storage encompassed both fixed and variable costs. Thus, the total cost of maize storage was obtained by summing up the fixed and variable costs. The fixed costs included the costs of the storage structures and small storage equipment, such as basins and baskets. Following Arouna et al. [20] the average monthly cost was calculated as:

$$
E(j)=\frac{C-R}{n}+[(C-R) * f+R] *(q-1)+C * r
$$

where $j$ is the type of storage structure or storage small equipment, $E(j)$ is the monthly cost of the storage structure or small storage equipment $j, C$ is the storage structure construction cost or purchase price, $R$ is the residual value of the storage structure or small storage equipment, $n$ is its useful lifespan, $(q-1)$ is the interest rate, $f$ is the capital asset factor, and $r$ is the repair or maintenance cost factor (coefficient). The capital asset factor is estimated using the formula as follows:

$$
\text { Capitalassetfactor }=(\text { Interestrate } / 100) * \text { maizesellingprice }
$$

In the study area, the small equipment was mostly not repaired and used until it was thrown away. Thus $R=0$ and $r=0$ and Equation (2) is written as follows:

$$
E(j)=\frac{C}{n}+C * f *(q-1)
$$

The variable costs of maize storage encompassed the costs associated with storage losses and other variable costs. The storage loss in monetary value, also called financial loss, represented the quantified sum of the quantitative losses occurring during storage with a given treatment. Thus, to calculate the quantitative loss, the quantity stored was multiplied by the loss rate. The financial loss was obtained by multiplying the quantitative loss by the average monthly maize selling price. The other variable costs comprised the labor costs associated with maize storage operations-including the dispatching and shelling costs of maize before storage in storage structures, the cost of loading and unloading the maize from the storage structure, the cost of the application of the conservation measure Actellic ${ }^{\circledR}$ Super and interest on the capital asset of the maize stock.

\subsubsection{Benefit-Cost Ratio (BCR)}

The benefit-cost ratio (BCR) was estimated for each treatment.

It was obtained by dividing the flow of the present value of the benefits (benefits) by that of the present value of the cost following the formula of Gittinger [18].

$$
\frac{B}{C}=\sum_{t=1}^{n} \frac{B_{t}}{(1+i)^{t-1}} / \sum_{t=1}^{n} \frac{C_{t}}{(1+i)^{t-1}}
$$

where $B_{t}$ is the monthly benefits, $C_{t}$ is the monthly costs, $n$ is the storage duration (in months), $i$ is the interest rate (expected) and $t$ is a given month.

\subsubsection{Break-Even Quantity}

The break-even quantity was estimated for each treatment, and thus, the break-even quantity of the turnover and the break-even ratio were determined.

The break-even quantity in turnover (BREQ) was calculated using the following formula:

$$
B R E Q=\left(\text { Fixedcosts } * \frac{\text { Revenue }}{\text { Grossmargin }}\right) * 100
$$

The percentage of capacity used, also called the break-even ratio, indicates the percentage of production for which the gross margin covers the fixed costs. The risk increases as the capacity percentage increases; a low percentage $($ maximum $=1)$ gives a level of security 
against unpredictable operating difficulties. Therefore, when the value of this capacity tends towards 1 , there is a risk in which the producer may no longer be able to pay for the equipment used. This percentage is computed by the following formula:

$$
\% \text { capacityused }=\left(\frac{B R E Q}{\text { Revenue }}\right) * 100
$$

The break-even quantity of maize to be stored in each storage and preservation technology to make the investment profitable is given by the following formula:

$$
\text { Break }- \text { evenquantity }=\% \text { capacityused } * \text { technicalcapacity }
$$

\subsubsection{Statistical Analysis}

The Student-Newman-Keuls (SNK) ANOVA statistical test was used to test the difference between the paired means between the different storage and conservation technologies using SPSS Statistics software. These paired multiple comparison tests captured the difference between paired means and generated a matrix that informed the means of groups of significantly different storage and conservation technologies [21].

\subsubsection{Sensitivity Analysis}

The sensitivity analysis consisted of varying the fixed costs and the selling prices of maize to assess the effect of the change in certain parameters (fixed costs and selling prices of maize) on the benefit-cost ratio and the threshold quantity for each of the technologies. This assessment allowed the impact of the different treatments implemented on the economic profitability of maize storage to be observed when these parameters changed for any reason.

\section{Results}

\subsection{Average Loss Rate Recorded for the Different Treatments Implemented}

The PICS bag with grain treatment and the PICS bag without grain treatment recorded fewer losses in the two communes during storage (Tables 1 and 2).

\begin{tabular}{|c|c|c|c|c|c|c|}
\hline Treatments & Month 1 & Month 2 & Month 3 & Month 4 & Month 5 & Month 6 \\
\hline Polypropylene bag - ctrol & $3.17 \pm 1.62 \% \mathrm{ab}$ & $5.17 \pm 1.76 \% b$ & $7.35 \pm 1.88 \%$ & $9.66 \pm 1.42 \%$ & $10.77 \pm 5.18 \%$ & $12.88 \pm 11.20 \%$ \\
\hline Polypropylene bag + ctrol & $1.64 \pm 0.43 \% \mathrm{ab}$ & $5.17 \pm 1.76 \% \mathrm{~b}$ & $5.62 \pm 4.52 \%$ & $9.32 \pm 2.28 \%$ & $9.62 \pm 5.25 \%$ & $10.56 \pm 2.80 \%$ \\
\hline PICS bag - ctrol & - & - & $4.85 \pm 1.36 \%$ & $9.00 \pm 3.71 \%$ & $10.08 \pm 4.61 \%$ & $11.71 \pm 2.78 \%$ \\
\hline PICS bag + ctrol & - & - & $3.77 \pm 1.49 \%$ & $7.24 \pm 1.28 \%$ & $9.17 \pm 1.82 \%$ & $9.42 \pm 4.64 \%$ \\
\hline Metal silo - ctrol & $2.83 \pm 1.67 \% \mathrm{~b}$ & $5.60 \pm 1.81 \% b$ & $11.94 \pm 5.64 \%$ & $13.07 \pm 4.83 \%$ & $13.78 \pm 6.79 \%$ & $14.61 \pm 9.13 \%$ \\
\hline Metal silo + ctrol & $1.62 \pm 0.65 \%$ a & $2.56 \pm 0.83 \%$ a & $3.03 \pm 0.99 \%$ & $10.22 \pm 3.18 \%$ & $11.79 \pm 2.56 \%$ & $14.07 \pm 6.73 \%$ \\
\hline Improved clay granary - ctrol & $4.15 \pm 2.41 \% \mathrm{ab}$ & $10.00 \pm 5.63 \% b$ & $10.19 \pm 4.03 \%$ & $13.84 \pm 3.77 \%$ & $21.69 \pm 6.23 \%$ & $22.64 \pm 7.21 \%$ \\
\hline Improved clay granary + ctrol & $0.70 \pm 0.41 \% \mathrm{ab}$ & $5.65 \pm 1.72 \% b$ & $8.99 \pm 3.18 \%$ & $12.19 \pm 0.63 \%$ & $16.66 \pm 2.10 \%$ & $20.90 \pm 0.20 \%$ \\
\hline Fisher test & $4.62^{* * *}$ & $2.17 * *$ & $1.53 \mathrm{~ns}$ & $1.28 \mathrm{~ns}$ & $0.65 \mathrm{~ns}$ & $0.814 \mathrm{~ns}$ \\
\hline
\end{tabular}

Table 1. Evolution of the average loss rates of the different treatments during storage in Savalou.

$p>$ F probabilities are indicated by symbols: $\mathrm{ns}=$ no significant differences; ${ }^{* *}$ significant differences at $p<0.05 ; * * *$ significant differences at $p<0.01$. For each column, values with the same letter indicate no significant differences at 5\%; Source: Experimentation data, 2015, 2016 and 2017 (- ctrol means: without chemical conservation measure; + ctrol means: with chemical conservation measure).

\begin{tabular}{|c|c|c|c|c|c|c|}
\hline Treatments & Month 1 & Month 2 & Month 3 & Month 4 & Month 5 & Month 6 \\
\hline Polypropylene bag - ctrol & $0.53 \pm 0.16 \% \mathrm{ab}$ & $1.84 \pm 0.90 \%$ & $4.79 \pm 1.97 \%$ & $7.98 \pm 1.87 \% \mathrm{ab}$ & $9.45 \pm 1.66 \% \mathrm{ab}$ & $9.64 \pm 2.73 \% \mathrm{ab}$ \\
\hline Polypropylene bag + ctrol & $0.45 \pm 0.24 \% \mathrm{ab}$ & $0.79 \pm 0.27 \%$ & $1.27 \pm 0.53 \%$ & $3.57 \pm 0.93 \%$ a & $3.28 \pm 0.86 \%$ a & $4.02 \pm 1.23 \%$ a \\
\hline PICS bag - ctrol & - & - & $3.42 \pm 0.90 \%$ & $5.30 \pm 1.65 \% \mathrm{ab}$ & $7.59 \pm 2.32 \% a b$ & $7.71 \pm 1.74 \% \mathrm{ab}$ \\
\hline PICS bag + ctrol & - & - & $0.85 \pm 0.33 \%$ & $2.09 \pm 0.68 \%$ a & $2.52 \pm 0.67 \%$ a & $2.69 \pm 0.77 \%$ a \\
\hline Metal silo - ctrol & $1.07 \pm 0.40 \% \mathrm{~b}$ & $1.70 \pm 0.51 \%$ & $3.88 \pm 1.27 \%$ & $7.77 \pm 2.02 \% b$ & $8.06 \pm 3.49 \% b$ & $11.26 \pm 2.93 \% b$ \\
\hline Metal silo + ctrol & $0.62 \pm 0.29 \% b$ & $1.69 \pm 0.72 \%$ & $3.55 \pm 1.22 \%$ & $4.08 \pm 1.97 \% \mathrm{ab}$ & $4.19 \pm 1.49 \%$ a & $4.92 \pm 1.36 \%$ a \\
\hline Improved clay granary - ctrol & $1.08 \pm 0.15 \% \mathrm{~b}$ & $2.16 \pm 0.90 \%$ & $4.89 \pm 1.24 \%$ & $10.04 \pm 1.87 \%$ ab & $10.18 \pm 2.07 \% \mathrm{ab}$ & $12.57 \pm 3.68 \% \mathrm{ab}$ \\
\hline Improved clay granary + ctrol & $0.57 \pm 0.31 \% \mathrm{ab}$ & $1.30 \pm 0.41 \%$ & $2.22 \pm 0.71 \%$ & $4.05 \pm 1.55 \% \mathrm{ab}$ & $4.09 \pm 1.12 \% \mathrm{ab}$ & $5.00 \pm 1.38 \% \mathrm{ab}$ \\
\hline Fisher test & $3.81^{* * *}$ & $3.06 \mathrm{~ns}$ & $2.44 \mathrm{~ns}$ & $3.34 * * *$ & $4.131 * * *$ & $3.093 * * *$ \\
\hline
\end{tabular}

Table 2. Evolution of the average loss rates of the different treatments during storage in Boukoumbé.

$p>$ F probabilities are indicated by symbols: $\mathrm{ns}=$ no significant differences; ${ }^{* *}$ significant differences at $p<0.05$; ${ }^{* * *}$ significant differences at $p<0.01$. For each column, values with the same letter indicate no significant differences at $5 \%$; Source: Experimentation data, 2015, 2016 and 2017 (- ctrol means: without chemical conservation measure; + ctrol means: with chemical conservation measure). 
The statistical differences observed showed that a significant increase in the loss of dry matter was observed at the level of each treatment throughout the six months of storage in Boukoumbé $(p<0.0001)$. In Savalou, significant variations were observed during the first two months. However, in the last month of storage, in the commune of Savalou, the PICS bag with a chemical conservation measure (9.42 $\pm 4.64 \%)$, the polypropylene bag with a chemical conservation measure $(10.56 \pm 2.80 \%)$ and the PICS bag without a chemical conservation measure $(11.71 \pm 2.78 \%)$ were the three treatments that recorded fewer losses, while the improved clay granary $(22.64 \pm 7.21 \%)$ recorded the highest loss rate (Table 2). In Boukoumbé, the PICS bag with a chemical conservation measure $(2.69 \pm 0.77 \%)$, the polypropylene bag with a chemical conservation measure $(4.02 \pm 1.23 \%)$ and the metal silo with a chemical conservation measure $(4.92 \pm 1.36 \%)$ were the treatments that recorded significantly fewer losses in order of priority, while the improved clay granary without a chemical conservation measure $(12.57 \pm 3.68 \%)$ was the treatment that recorded the most maize loss during storage $(\mathrm{F}=3.093, p<0.0001)$ (Table 2).

\subsection{Pests in Experimental Trials}

Regarding the pest infestation, the treatments including the chemical conservation measure recorded the lowest insect populations. Application of the chemical conservation measure decreased the infestation by insects significantly. As a result, the application of the chemical conservation measure improved the efficacy of control of the insect population. The treatments most affected by these pests were, in decreasing order, the improved clay granary without a chemical conservation measure, the polypropylene bag without a chemical conservation measure and the metal silo without a chemical conservation measure. The PICS bag and the ZeroFly ${ }^{\circledR}$ Bag without chemical conservation measure recorded a lower insect pest population. Therefore, these two technologies are likely to better protect stocks against insects.

Sitophilus zeamaïs was the primary pest counted, and a few Dinoderus spp. were observed during the identification carried out in the laboratory for the first year. In Savalou, there was a heavy infestation of grain stocks by beetles. In Boukoumbé, the number of beetles counted for all treatments remained relatively lower compared to the count carried out in Savalou. For two years, Sitophilus zeamaïs (primary) and Tribolium castaneum (secondary) were the two main pests (insects) counted during the identification carried out in the laboratory. In Savalou, we noted a high infestation of grain stocks by these two beetles, the most abundant of which was Sitophilus zeamaïs. In Boukoumbé, the same insects were counted, and the most abundant was Tribolium castaneum. However, the number of insects counted at all the treatments remained relatively lower in Boukoumbe than in Savalou.

\subsection{Financial Analysis of the Treatments Implemented}

The results from the evaluation of the loss rates of the treatments were used to calculate the amount of financial loss at the level of each treatment. Details on monthly costs of maize storage in each storage structure involved in trials are presented in the supplementary materials, Tables S1-S4.

\subsubsection{Storage Costs}

The results showed that the fixed costs for the metal silo with $(25.88$ FCFA $/ \mathrm{kg})$ and without (31.61 CFAF $/ \mathrm{kg}$ ) chemical conservation measures, and the improved granary with $(15.67 \mathrm{CFAF} / \mathrm{kg})$ and without $(26.1 \mathrm{CFAF} / \mathrm{kg})$ conservation measure were statistically superior to that of the polypropylene bag and PICS bag $(p<0.001)$, whatever the municipality (Tables 3 and 4 ). The same trends were observed with regard to total costs, which involved both fixed and variable costs. In fact, the storage structures with a long lifespan (metal silo and improved earthen granary) had total maize storage costs of more than CFAF $100 / \mathrm{kg}$ while storage structures (polypropylene bag and PICS bag) had total storage costs of less than CFAF $100 / \mathrm{kg}$. This was explained by the fixed costs and costs 
related to financial losses, which were statistically higher for the structures with a long lifespan, especially without lifespan $(\mathrm{F}=3.24, p<0.05)$. This referred to the case of the metal silo without a chemical conservation measure, whose fixed costs and costs related to financial losses were higher than those of other treatments. The market price of maize does not vary according to the storage structure or whether the producer has used a chemical conservation measure. Thus, the discounted income, which corresponded to the selling price of one kilogram of maize, did not vary according to treatment, and the discounted income was CFAF 498.93 per kilogram of maize stored over a period of 6 months in Savalou.

The total costs of storing maize were all less than CFAF 100 in the commune of Boukoumbé (Table 4). The statistical difference showed that the lowest cost of storage of maize was recorded at the level of the polypropylene bag without a chemical conservation measure (CFAF 54.55) $(\mathrm{F}=1.46, p<0.05)$. The metal silo with chemical conservation measure, on the other hand, recorded the highest total cost of storing and conserving maize (CFAF 90.87). The improved clay granary without a chemical conservation measure recorded the highest financial loss (CFAF 9.24), while the PICS bag with a chemical conservation measure recorded the lowest financial loss (CFAF 2.07) $(\mathrm{F}=1.46 ; p<0.05)$ (Table 4$)$. The discounted income was CFAF 389.30 in this commune for one kilogram of maize stored for six (06) months.

\subsubsection{Benefit-Cost Ratio}

The calculated benefit-cost ratios were all greater than 1 , and, therefore, when the producer invested 1 CFAF for the storage and conservation of one kilogram of maize, he or she obtained an income of more than 1 CFAF $/ \mathrm{kg}$. In Savalou, the storage of maize in the PICS bag (10.87), polypropylene bag (7.89) and improved granary (7.53) without chemical conservation measure, by order of priority, had the highest benefit-cost ratio compared to other structures $(\mathrm{F}=2.01 ; p<0.05)$ (Table 3$)$. In other words, the storage of one kilogram of maize in the PICS bag, polypropylene bag and improved granary without chemical conservation measures generated an income of $10.87,7.89$ and 7.53 CFAF, respectively for an investment of 1 CFAF $/ \mathrm{kg}$.

The polypropylene bag had an average benefit-cost ratio that was statistically lower than that of the PICS bag without chemical conservation measure. This means that producers of maize in Savalou can use all the other maize storage structures and chemical conservation measures except the untreated PICS bag for maize storage in place of the polypropylene bag with chemical conservation measures. In the same vein, the lowest value of the income generated was observed, especially at the level of the metal silo, with $(4.58 \mathrm{CFAF} / \mathrm{kg})$ and without $(4.00 \mathrm{CFAF} / \mathrm{kg})$ chemical conservation measures. Therefore, storing maize in the improved granary without a chemical conservation measure gave the lowest benefit-cost ratio. In Boukoumbé, the storage of maize in the polypropylene bag and PICS bag without a chemical conservation measure generated an income of 7.42 and 7.30 CFAF $/ \mathrm{kg}$, respectively, for an investment of 1 FCFA. This was statistically higher than the value generated by the other storage structures (improved clay granary, metal silo with or without grain treatment) $(\mathrm{F}=14.01 ; p<0.001)$ (Table 4). Unlike Savalou, the income generated with the storage of maize in the polypropylene bag was relatively higher than the PICS bag without a chemical conservation measure in Boukoumbé. Consequently, producers in Boukoumbé should use the PICS bag with a chemical conservation measure in place of the polypropylene bag with a chemical conservation measure or the improved clay granary with or without a chemical conservation measure in place of the polypropylene bag with a chemical conservation measure. 
Table 3. Benefit-cost ratio and break-even quantity of the different treatments implemented in Savalou.

\begin{tabular}{|c|c|c|c|c|c|c|c|c|}
\hline \multirow{4}{*}{ Treatments } & \multicolumn{8}{|c|}{ Savalou } \\
\hline & \multirow{3}{*}{$\begin{array}{c}\text { Discoun-ted } \\
\text { Total Revenue } \\
\text { * (CFAF/Kg) }\end{array}$} & \multicolumn{5}{|c|}{ Discounted Storage Costs (CFAF/kg) } & \multicolumn{2}{|c|}{$\begin{array}{c}\text { Financial Profitability } \\
\text { Parameters }\end{array}$} \\
\hline & & \multirow[b]{2}{*}{ Fix Costs } & \multicolumn{3}{|c|}{ Variables Costs } & \multirow[b]{2}{*}{ Total Costs } & \multirow[b]{2}{*}{ BCR } & \multirow[b]{2}{*}{$\begin{array}{c}\text { Break-Even } \\
\text { Quantity (kg) }\end{array}$} \\
\hline & & & $\begin{array}{l}\text { Storage Loss } \\
\text { Cost }\end{array}$ & $\begin{array}{c}\text { Other } \\
\text { Variable Costs }\end{array}$ & $\begin{array}{c}\text { Total } \\
\text { variable } \\
\text { Costs }\end{array}$ & & & \\
\hline Polyp bag - ctrol & 498.93 & $1.21 \mathrm{a}$ & $23.01 \mathrm{~b}$ & 63.77 & $86.78 \mathrm{~b}$ & $87.99 \mathrm{a}$ & $7.89 \mathrm{~b}$ & $31.24 \mathrm{a}$ \\
\hline Polyp bag + ctrol & 498.93 & $1.21 \mathrm{a}$ & $17.38 \mathrm{ab}$ & 71.16 & $88.54 \mathrm{ab}$ & $89.75 \mathrm{ab}$ & $5.76 \mathrm{ab}$ & $30.97 \mathrm{a}$ \\
\hline PICS bag - ctrol & 498.93 & $3.94 \mathrm{a}$ & $10.25 \mathrm{a}$ & 63.77 & $74.02 \mathrm{a}$ & $77.96 \mathrm{a}$ & $10.87 \mathrm{~b}$ & $97.94 \mathrm{~b}$ \\
\hline PICS bag + ctrol & 498.93 & $3.94 \mathrm{a}$ & $8.68 \mathrm{a}$ & 71.16 & $79.84 \mathrm{ab}$ & $83.78 \mathrm{a}$ & $6.18 \mathrm{ab}$ & $98.52 \mathrm{~b}$ \\
\hline Metal silo - ctrol & 498.93 & $31.85 \mathrm{~b}$ & $31.61 \mathrm{ab}$ & 63.77 & $95.38 \mathrm{ab}$ & $127.23 \mathrm{~b}$ & $4.00 \mathrm{a}$ & $848.86 \mathrm{~d}$ \\
\hline Metal silo + ctrol & 498.93 & $31.85 \mathrm{~b}$ & $25.88 \mathrm{~b}$ & 71.16 & $97.04 \mathrm{~b}$ & $128.89 \mathrm{~b}$ & $4.58 \mathrm{a}$ & $821.35 \mathrm{~d}$ \\
\hline Imp. clay granary - ctrol & 498.93 & $15.08 \mathrm{~b}$ & $26.1 \mathrm{ab}$ & 63.77 & $89.87 \mathrm{ab}$ & $104.95 \mathrm{ab}$ & $7.53 \mathrm{~b}$ & $351.02 \mathrm{c}$ \\
\hline Imp. clay granary+ ctrol & 498.93 & $15.08 \mathrm{~b}$ & $15.67 \mathrm{ab}$ & 71.16 & $86.83 \mathrm{~b}$ & $101.91 \mathrm{ab}$ & $5.32 \mathrm{ab}$ & $369.22 \mathrm{c}$ \\
\hline Fisher test & & $1.69^{* * *}$ & $3.24 * *$ & $8.33 \mathrm{~ns}$ & $0.29 * *$ & $1.84^{* *}$ & $2.01 * *$ & $16.05^{* * *}$ \\
\hline
\end{tabular}

$*$ = Average selling prices of one $\mathrm{kg}$ of maize is 498.93 CFAF in Savalou; $p>$ F probabilities are indicated by symbols: $\mathrm{ns}=$ no significant differences; ${ }^{* *}=$ significant differences at $p<0.05 ;{ }^{* * *}=$ significant differences at $p<0.01$. For each column, values with the same letter indicate no significant differences at 5\%. Source: Experimentation data, 2015, 2016 and 2017 ( - ctrol = without chemical conservation measure; + ctrol $=$ with chemical conservation measure).

Table 4. Benefit-cost ratio and break-even quantity of the different treatments implemented in Boukoumbé.

\begin{tabular}{|c|c|c|c|c|c|c|c|c|}
\hline \multirow{4}{*}{ Treatments } & \multicolumn{8}{|c|}{ Boukoumbé } \\
\hline & \multirow{3}{*}{$\begin{array}{l}\text { Discoun-ted } \\
\text { Total Revenue } \\
* \text { (CFAF/Kg) }\end{array}$} & \multicolumn{5}{|c|}{ Discounted Storage Costs (CFAF/kg) } & \multicolumn{2}{|c|}{$\begin{array}{c}\text { Financial Profitability } \\
\text { Parameters }\end{array}$} \\
\hline & & \multirow[b]{2}{*}{ Fix Costs } & \multicolumn{3}{|c|}{ Variables Costs } & \multirow[b]{2}{*}{ Total Costs } & \multirow[b]{2}{*}{ BCR } & \multirow[b]{2}{*}{ Break-(kg) } \\
\hline & & & $\begin{array}{l}\text { Storage Loss } \\
\text { Cost }\end{array}$ & $\begin{array}{c}\text { Other } \\
\text { Variable Costs }\end{array}$ & $\begin{array}{c}\text { Total } \\
\text { Variable } \\
\text { Costs }\end{array}$ & & & \\
\hline Polyp bag - ctrol & 389.30 & $1.21 \mathrm{a}$ & $6.01 \mathrm{bc}$ & 47.33 & $53.34 \mathrm{ab}$ & $54.55 \mathrm{a}$ & $7.42 \mathrm{c}$ & $37.46 \mathrm{a}$ \\
\hline Polyp bag + ctrol & 389.30 & $1.21 \mathrm{a}$ & $3.52 \mathrm{a}$ & 54.47 & $57.99 \mathrm{ab}$ & $59.2 \mathrm{ab}$ & $6.12 b c$ & $38.27 \mathrm{a}$ \\
\hline PICS bag - ctrol & 389.30 & $4.30 \mathrm{a}$ & $3.58 \mathrm{ab}$ & 47.33 & $50.91 \mathrm{a}$ & $55.21 \mathrm{a}$ & $7.30 \mathrm{c}$ & $132.32 \mathrm{~b}$ \\
\hline PICS bag + ctrol & 389.30 & $4.30 \mathrm{a}$ & $2.07 \mathrm{a}$ & 54.47 & $56.54 \mathrm{ab}$ & $60.84 \mathrm{ab}$ & $6.00 \mathrm{bc}$ & $134.91 \mathrm{~b}$ \\
\hline Metal silo - ctrol & 389.30 & $31.54 \mathrm{~b}$ & $7.85 \mathrm{bc}$ & 47.33 & $55.18 \mathrm{ab}$ & $86.72 \mathrm{c}$ & $4.71 \mathrm{a}$ & $932.62 \mathrm{~d}$ \\
\hline Metal silo + ctrol & 389.30 & $31.54 \mathrm{~b}$ & $4.86 \mathrm{ab}$ & 54.47 & $59.33 \mathrm{~b}$ & $90.87 \mathrm{c}$ & $4.24 \mathrm{a}$ & $946.72 \mathrm{~d}$ \\
\hline Imp. Clay granary - ctrol & 389.30 & $11.63 \mathrm{~b}$ & $9.24 \mathrm{c}$ & 47.33 & $56.57 \mathrm{ab}$ & $68.2 \mathrm{bc}$ & $6.08 \mathrm{c}$ & $346.30 \mathrm{c}$ \\
\hline Imp. Clay granary+ ctrol & 389.30 & $11.63 \mathrm{~b}$ & $7.61 \mathrm{bc}$ & 54.47 & $62.08 \mathrm{~b}$ & $73.71 \mathrm{bc}$ & $5.54 \mathrm{ab}$ & $317.41 \mathrm{c}$ \\
\hline Fisher test & & $5.31 * * *$ & $0.40^{* * *}$ & $4.31 \mathrm{~ns}$ & $0.63 * *$ & $1.46 * *$ & $14.01 * * *$ & $1.03 *$ \\
\hline
\end{tabular}

$*$ = Average selling prices of one $\mathrm{kg}$ of maize is 389.30 CFAF in Boukoumbé; $p>$ F probabilities are indicated by symbols: $\mathrm{ns}=$ no significant differences; ${ }^{* *}=$ significant differences at $p<0.05 ;{ }^{* * *}=$ significant differences at $p<0.01$. For each column, values with the same letter indicate no significant differences at 5\%. Source: Experimentation data, 2015, 2016 and 2017 ( - ctrol = without chemical conservation measure treatment; + ctrol $=$ with chemical conservation measure) .

\subsubsection{Break-Even Quantity}

The break-even quantity is the minimum quantity that the storage technology can contain to allow the producer to return on an investment for the purchase of the storage structure. In general, in the two municipalities, the results indicated that a large quantity of approximately one ton must be stored in the metal silo to make the investment profitable. In fact, considering its initial investment, the metal silo presented a large break-even quantity compared to all the other technologies $(\mathrm{F}=16.05 p<0.001$ in Savalou; $\mathrm{F}=1.03$ $p<0.001$ in Boukoumbé) (Tables 3 and 4). The break-even quantity was variable depending on the treatment. In Savalou, the metal silo without grain treatment presented a breakeven quantity value of $848.86 \mathrm{~kg}$ compared to $821.35 \mathrm{~kg}$ for the metal silo with grain treatment (Table 3). The polypropylene bag without grain treatment had a threshold capacity of $31.24 \mathrm{~kg}$ compared to $30.97 \mathrm{~kg}$ for the polypropylene bag with grain treatment (Table 3). The PICS bag without grain treatment presented a break-even quantity of $97.94 \mathrm{~kg}$ compared to $98.52 \mathrm{~kg}$ for the PICS bag with grain treatment. The closed ground granary without grain treatment presented a break-even quantity of $351.02 \mathrm{~kg}$, and the improved clay granary with grain treatment presented a break-even quantity of $369.22 \mathrm{~kg}$. 
In Boukoumbé, the PICS bag presented a break-even quantity exceeding $100 \mathrm{~kg}$. The PICS bag without grain treatment yielded $132.32 \mathrm{~kg}$, while the metal silo with grain treatment yielded $946.72 \mathrm{~kg}$ (Table 4). The break-even quantity for the metal silo was approximately one ton, while the improved clay granary presented a break-even quantity of less than $500 \mathrm{~kg}$. The metal silo without grain treatment yielded $932.62 \mathrm{~kg}$, compared to $946.72 \mathrm{~kg}$ for the metal silo with grain treatment. The improved clay granary without grain treatment presented a break-even quantity of $346.30 \mathrm{~kg}$, and the improved clay granary without treatment presented a break-even quantity of $317.41 \mathrm{~kg}$.

\subsubsection{Analysis of the Sensitivity of the Benefit-Cost Ratio and of the Break-Even Quantity}

Tables 5 and 6 present the results of the sensitivity analysis of the benefit-cost ratio and the break-even quantity of the treatments implemented in Savalou and Boukoumbé. On the one hand, we increased the fixed costs by $10 \%$ and decreased the selling price of maize by $30 \%$ and $40 \%$. On the other hand, we increased the fixed costs by $10 \%$ and the selling price of maize by $30 \%$ and $40 \%$. In the two (02) municipalities, the results showed that the break-even quantity was the most sensitive indicator to variations in the fixed costs of storing maize and the selling price of maize.

Rising fixed costs of $10 \%$ and a decrease in maize sales price implies a decrease in the benefit-cost ratio value, whatever the type of structure. The polypropylene bag and PICS bag without grain treatment had the highest benefit-cost ratio compared to other structures, with an increased fixed cost of approximately $10 \%$, and a decrease in maize sales price by $30 \%$ and $40 \%(\mathrm{~F}=0.95 ; p<0.05)$. The same trends were observed following an increase in the maize sales price by $30 \%$ and $40 \%$; however, the improved clay granary also had the highest benefit-cost ratio. In Savalou, the reduction of the selling price of maize by $40 \%$ (compared to the current selling price of maize) caused the polypropylene bag without grain treatment to no longer be profitable for maize storage for a break-even quantity of $-1322.34 \mathrm{~kg}$, given its statistically low value compared to that of other structures $(p<0.001)$ (Table 5). The result was the same for the metal silo without treatment, which became unprofitable following $30 \%$ and $40 \%$ reductions in the selling price of maize, with the break-even quantity changing from 166.06 to $-22.40 \mathrm{~kg}$. On the contrary, an increase in the selling price of maize by $30 \%$ or $40 \%$ caused the metal silo to be profitable for maize storage for break-even quantity.

In Boukoumbé, the metal silo with and without grain treatment constitutes the main storage and preservation technology, and the break-even quantity of this technology is very sensitive to variations in the selling price of maize. However, the storage of maize remained profitable, given its statistically high value compared to that of other structures $(p<0.001)$. Indeed, the break-even quantity increased from 150.63 to $198.40 \mathrm{~kg}$ for the storage of maize in the metal silo without grain treatment, with reductions in the selling price of maize of $30 \%$ and $40 \%$, respectively (Table 6 ). For the metal silo with grain treatment, the break-even quantity increased from 147.60 to $181.46 \mathrm{~kg}$ and then to $235.60 \mathrm{~kg}$ (Table 6). On the contrary, a decrease in the break-even quantity was observed with regard to an increase in the selling price of maize. The same trends were observed in Saval. 
Table 5. Sensitivity analysis of the benefit-cost ratio and the break-even quantity of the different treatments implemented in Savalou.

\begin{tabular}{|c|c|c|c|c|c|c|c|c|c|c|c|c|c|}
\hline \multirow[b]{2}{*}{ Treatments } & \multirow{2}{*}{$\begin{array}{l}10 \% \text { Increase } \\
\text { in Fixed } \\
\text { Costs }\end{array}$} & \multicolumn{3}{|c|}{$\begin{array}{l}\text { 10\% Increase in Fixed Costs and } 30 \% \\
\text { Decrease in Maize Sales Price }\end{array}$} & \multicolumn{3}{|c|}{$\begin{array}{l}10 \% \text { Increase in Fixed Costs and } 40 \% \text { Decrease } \\
\text { in Maize Sales Price }\end{array}$} & \multicolumn{3}{|c|}{$\begin{array}{l}\text { 10\% Increase in Fixed Costs and } 30 \% \\
\text { Increase in Maize Sales Price } \\
\end{array}$} & \multicolumn{3}{|c|}{$\begin{array}{l}\text { 10\% Increase in Fixed Costs and } 40 \% \\
\text { Increase in Maize Sales Price }\end{array}$} \\
\hline & & $\begin{array}{c}30 \% \text { Decrease } \\
\text { in Maize Sales } \\
\text { Price }\end{array}$ & BCR & $\begin{array}{c}\text { Break-Even } \\
\text { Quantity } \\
\text { (kg) }\end{array}$ & $\begin{array}{c}40 \% \text { Decrease } \\
\text { in Maize Sales } \\
\text { Price }\end{array}$ & BCR & $\begin{array}{l}\text { Break-Even } \\
\text { Quantity (kg) }\end{array}$ & $\begin{array}{l}30 \% \text { Increase in } \\
\text { Maize Sales } \\
\text { Price }\end{array}$ & BCR & $\begin{array}{c}\text { Break-Even } \\
\text { Quantity } \\
\text { (kg) }\end{array}$ & $\begin{array}{l}40 \% \text { Increase in } \\
\text { Maize Sales } \\
\text { Price }\end{array}$ & BCR & $\begin{array}{c}\text { Break- } \\
\text { Even } \\
\text { Quantity } \\
\text { (kg) }\end{array}$ \\
\hline Polyp bag - ctrol & $0.12 \mathrm{~b}$ & 363.38 & $5.71 \mathrm{~b}$ & $5.54 \mathrm{a}$ & 311.47 & $4.89 \mathrm{c}$ & $-1322.34 \mathrm{ab}$ & 674.86 & $10.60 \mathrm{~b}$ & $84.28 \mathrm{a}$ & 726.77 & $11.42 \mathrm{~b}$ & $78.25 \mathrm{a}$ \\
\hline Polyp bag + ctrol & $0.12 \mathrm{~b}$ & 339.85 & $4.24 \mathrm{ab}$ & $5.02 \mathrm{a}$ & 291.30 & $3.63 \mathrm{ab}$ & $6.39 \mathrm{~b}$ & 631.16 & $7.88 \mathrm{ab}$ & $94.69 \mathrm{a}$ & 679.71 & $8.49 \mathrm{ab}$ & $87.90 \mathrm{a}$ \\
\hline PICS bag - ctrol & $0.39 a$ & 363.38 & $5.83 \mathrm{~b}$ & $16.55 \mathrm{~b}$ & 311.47 & $5.00 \mathrm{c}$ & $28.79 \mathrm{bc}$ & 674.86 & $10.84 \mathrm{~b}$ & $104.73 \mathrm{~b}$ & 726.77 & $11.68 \mathrm{~b}$ & $99.73 \mathrm{~b}$ \\
\hline PICS bag + ctrol & $0.39 a$ & 339.85 & $4.32 \mathrm{ab}$ & $15.75 \mathrm{~b}$ & 291.30 & $3.70 \mathrm{ab}$ & $19.84 \mathrm{bc}$ & 631.16 & $8.04 \mathrm{ab}$ & $107.26 \mathrm{~b}$ & 679.71 & $8.65 \mathrm{ab}$ & $96.50 \mathrm{~b}$ \\
\hline Metal silo - ctrol & $3.18 \mathrm{~d}$ & 382.63 & $4.32 \mathrm{ab}$ & $166.06 \mathrm{~d}$ & 327.97 & $3.70 \mathrm{ab}$ & $-22.40 \mathrm{ab}$ & 710.61 & $6.90 \mathrm{a}$ & $285.26 c$ & 765.27 & $7.43 \mathrm{a}$ & 279.16 c \\
\hline Metal silo + ctrol & $3.18 \mathrm{~d}$ & 354.15 & $3.66 \mathrm{a}$ & $138.88 \mathrm{~d}$ & 303.55 & $3.14 \mathrm{ab}$ & $185.87 \mathrm{~d}$ & 657.71 & $5.22 \mathrm{a}$ & $298.66 \mathrm{c}$ & 708.30 & $5.62 \mathrm{a}$ & $291.59 \mathrm{c}$ \\
\hline Imp. Clay granary+ ctrol & $1.51 \mathrm{c}$ & 345.27 & $2.81 \mathrm{a}$ & $58.33 \mathrm{c}$ & 295.95 & $2.40 \mathrm{a}$ & $72.4 \mathrm{c}$ & 641.23 & $6.81 \mathrm{a}$ & $184.67 \mathrm{~d}$ & 690.56 & $\begin{array}{l}7.33^{a} \\
4 * * *\end{array}$ & $167.88 \mathrm{~d}$ \\
\hline Fisher test & 1.30 & & $0.95^{* *}$ & $6.61^{* * *}$ & & 0.47 * & $5.44^{* *}$ & & $7.64^{* *}$ & $2.96^{* * *}$ & & $4.71^{* * *}$ & $9.33^{* * *}$ \\
\hline
\end{tabular}

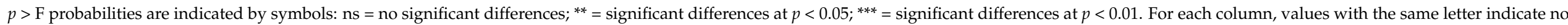
significant differences at 5\%. Source: Experimentation data from 2015, 2016 and 2017 ( - ctrol $=$ without chemical conservation measure; + ctrol = with chemical conservation measure).

Table 6. Sensitivity analysis of the benefit-cost ratio and the break-even quantity of the different treatments implemented in Boukoumbé.

\begin{tabular}{|c|c|c|c|c|c|c|c|c|c|c|c|c|c|}
\hline \multirow[b]{2}{*}{ Treatments } & \multirow[b]{2}{*}{$\begin{array}{l}10 \% \text { Increase } \\
\text { in Fixed } \\
\text { Costs }\end{array}$} & \multicolumn{3}{|c|}{$\begin{array}{l}10 \% \text { Increase in Fixed Costs and } 30 \% \\
\text { Decrease in Maize Sales Price }\end{array}$} & \multicolumn{3}{|c|}{$\begin{array}{l}10 \% \text { Increase in Fixed Costs and } 40 \% \text { Decrease } \\
\text { in Maize Sales Price }\end{array}$} & \multicolumn{3}{|c|}{$\begin{array}{l}10 \% \text { Increase in Fixed Costs and } 30 \% \\
\text { Increase in Maize Sales Price }\end{array}$} & \multicolumn{3}{|c|}{$\begin{array}{l}\text { 10\% Increase in Fixed Costs and } 40 \% \\
\text { Increase in Maize Sales Price }\end{array}$} \\
\hline & & $\begin{array}{c}30 \% \text { Decrease } \\
\text { in Maize Sales } \\
\text { Price }\end{array}$ & BCR & $\begin{array}{l}\text { Break- } \\
\text { Even } \\
\text { Quantity } \\
\text { (kg) }\end{array}$ & $\begin{array}{c}40 \% \text { Decrease } \\
\text { in Maize Sales } \\
\text { Price }\end{array}$ & BCR & $\begin{array}{c}\text { Break-Even } \\
\text { Quantity (kg) }\end{array}$ & $\begin{array}{l}\text { 30\% Increase in } \\
\text { Maize Sales } \\
\text { Price }\end{array}$ & BCR & $\begin{array}{c}\text { Break- } \\
\text { Even } \\
\text { Quantity } \\
\text { (kg) }\end{array}$ & $\begin{array}{l}40 \% \text { Increase in } \\
\text { Maize Sales } \\
\text { Price }\end{array}$ & BCR & $\begin{array}{c}\text { Break- } \\
\text { Even } \\
\text { Quantity } \\
\text { (kg) }\end{array}$ \\
\hline Polyp bag - ctrol & $0.12 \mathrm{a}$ & 278.13 & $4.93 \mathrm{~b}$ & $5.90 \mathrm{a}$ & 238.40 & $4.22 \mathrm{~b}$ & $7.49 \mathrm{a}$ & 516.55 & $9.16 \mathrm{~b}$ & $87.56 \mathrm{a}$ & 556.28 & $9.87 \mathrm{~b}$ & $81.29 \mathrm{a}$ \\
\hline Polyp bag + ctrol & $0.12 \mathrm{a}$ & 267.41 & $4.18 \mathrm{ab}$ & 5.98 a & 229.21 & $3.58 \mathrm{ab}$ & $7.36 \mathrm{a}$ & 496.63 & $7.77 \mathrm{ab}$ & $92.53 \mathrm{a}$ & 534.83 & $8.37 \mathrm{ab}$ & $85.90 \mathrm{a}$ \\
\hline PICS bag - ctrol & $0.43 \mathrm{~b}$ & 282.95 & $4.95 \mathrm{~b}$ & $20.72 \mathrm{~b}$ & 242.53 & $4.24 \mathrm{~b}$ & $26.09 \mathrm{~b}$ & 525.49 & $9.19 \mathrm{~b}$ & $106.06 \mathrm{~b}$ & 565.91 & $9.90 \mathrm{~b}$ & $101.89 \mathrm{~b}$ \\
\hline PICS bag + ctrol & $0.43 \mathrm{~b}$ & 267.41 & $4.06 \mathrm{ab}$ & $21.02 \mathrm{~b}$ & 229.21 & $3.48 \mathrm{ab}$ & $25.84 \mathrm{~b}$ & 496.63 & $7.54 \mathrm{ab}$ & $111.91 \mathrm{~b}$ & 534.83 & $8.12 \mathrm{ab}$ & $106.25 \mathrm{~b}$ \\
\hline Metal silo - ctrol & $3.15 \mathrm{~d}$ & 296.64 & $4.31 \mathrm{ab}$ & $150.63 \mathrm{~d}$ & 254.26 & $3.70 \mathrm{~b}$ & $198.40 \mathrm{~d}$ & 550.91 & 5.96 a & $282.16 \mathrm{c}$ & 593.29 & $6.42 \mathrm{a}$ & $261.84 \mathrm{c}$ \\
\hline Metal silo + ctrol & $3.15 \mathrm{~d}$ & 296.74 & 3.87 a & $147.60 \mathrm{~d}$ & 254.35 & $3.32 \mathrm{a}$ & $181.46 \mathrm{~d}$ & 551.10 & $5.62 \mathrm{a}$ & $288.75 \mathrm{c}$ & 593.49 & $6.06 \mathrm{a}$ & $272.40 \mathrm{c}$ \\
\hline Imp. Clay granary+ ctrol & $1.16 \mathrm{c}$ & 297.33 & $3.02 \mathrm{a}$ & $48.76 \mathrm{c}$ & 254.85 & $2.59 \mathrm{a}$ & $59.42 \mathrm{c}$ & 552.19 & $7.20 \mathrm{ab}$ & $184.63 \mathrm{~d}$ & 594.67 & $7.76 \mathrm{ab}$ & $198.57 \mathrm{~d}$ \\
\hline Fisher test & 0.63 & & $0.41^{* * *}$ & $1.30^{* * *}$ & & $0.64^{* *}$ & $7.14^{* * *}$ & & $1.31^{* * *}$ & $6.95^{* * *}$ & & $5.35 * * *$ & $2.54^{* * *}$ \\
\hline
\end{tabular}

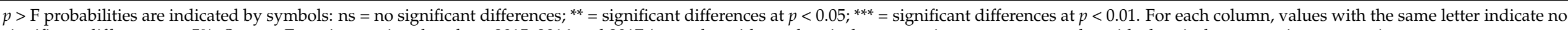
significant differences at 5\%. Source: Experimentation data from 2015, 2016 and 2017 ( - ctrol $=$ without chemical conservation measure; + ctrol = with chemical conservation measure). 


\section{Discussion}

Regardless of municipality, the PICS bag recorded the lowest loss rate. The PICS bag with treatment recorded total losses of $9.42 \%( \pm 4.64 \%)$, and the PICS bag without a chemical control recorded total losses of $11.71 \%( \pm 2.78 \%)$ in Savalou. The PICS bag with grain treatment recorded total losses of $2.69 \%( \pm 0.77 \%)$, and the PICS bag without chemical control recorded total losses of $7.71 \%( \pm 1.74 \%)$ in Boukoumbé. Our findings agreed with results obtained by Poudel et al. [22], who evaluated the efficiency of maize storage and conservation structures in Central and Northern Benin and concluded that in Savalou, as in Boukoumbé, the PICS bag without grain treatment with Actellic ${ }^{\circledR}$ Super was more effective than the untreated polypropylene bag for reducing loss rates.

Sitophilus zeamaïs and Tribolium castaneum were the two main pests counted in stocks, and the better pest control technology was the PICS bag. Pests were more common in Savalou than in Boukoumbé. This may be because Savalou is a humid area, and Boukoumbé is a dry area. However, the assessment of pest levels compared to temperature or moisture was not studied.

The benefit-cost ratio of the PICS bag without a chemical conservation measure was the highest (7.89) in the Savalou region. Ndegwa et al. [23] found a similar result and observed that airtight bags (the PICS bag and the SuperGrain Bag) without preservatives exhibited the highest benefit-cost ratio of 1.6, with a loss rate of $3.9 \%$ over four months of storage in Kenya.

The benefit-cost ratio of the metal silo in Savalou was 5.86 without the chemical conservation measure and 4.99 with the chemical control. This ratio for the metal silo was 6.20 without the chemical protectant and 5.28 with the chemical protectant measure in Boukoumbé. Compared to the improved clay granary, the metal silo displayed the highest ratios regardless of region. The metal silo had a ratio of 4.99, compared to the improved clay granary without and with conservation measure, which presented benefit-cost ratios of 4.85 and 3.63 in Savalou, respectively, and 4.35 and 4.18, respectively, in Boukoumbé, and was more profitable. Our findings agreed with results obtained by Nduku et al. [24], who performed a comparative analysis of the metal silo with storage technologies in a traditional improved granary in Kenya. The highest ratios obtained for the metal silo and the improved traditional granary were 2.5 and 1.6, respectively. Similarly, the metal silo was profitable at a break-even quantity of $1000 \mathrm{~kg}$, regardless of the level of variation of maize sales price at Boukoumbé. It was in this context that De Groote et al. [13] proposed assessing the cost per kilogram of grain stored for different capacities of metal silos to determine the type of metal silo that would be financially and economically profitable.

The untreated polypropylene bag had the highest benefit-cost ratio of 6.91 in the northern region. We observed that agroclimatic conditions influenced the efficiency and the profitability of storage technologies; however, our research did not address these aspects.

For both Central and Northern Benin, the improved clay granary with chemical conservation measure was more expensive than the reference technology (here, the polypropylene bag with the chemical control). Adégbola et al. [3] found a similar result and indicated that the improved clay granary was more expensive than the reference system (traditional granary with treatment using local products) in southern Benin.

\section{Conclusions}

To identify strategies that reduced postharvest losses of maize and improved maize storage, conservation technologies were introduced in central and northern Benin. The loss rates and financial profitability of these different storage and conservation technologies were assessed. The analysis showed that, in central and northern Benin, the PICS bag and the polypropylene bag recorded less storage losses and were more profitable than the improved and closed earth granary and the metal silo. Specifically, the PICS bag without treatment was more profitable in Savalou, and the polypropylene bag with treatment was more profitable in Boukoumbé. The PICS bag and the polypropylene bag had a low initial investment cost compared to the improved clay granary and the metal silo, 
which had a high initial investment cost. The metal silo was also found to be more efficient and profitable than the improved clay granary, but the initial investment for the metal silo was high, and it was profitable at a break-even quantity of $1000 \mathrm{~kg}$. To facilitate the dissemination and adoption of the metal silo, especially by small producers, a reduction in import taxes on galvanized sheet metal, which is the raw material for manufacturing metal silos, may help reduce the cost. In addition, appropriations adapted to the storage of grains in these technologies will have to accompany their diffusion. The PICS bag and the polypropylene bag are plastic bags, the recycling of which takes time after use. Governments should take responsibility for reducing the import taxes on galvanized sheet metal to facilitate the distribution and use of the metal silo; however, storage in bags facilitates transportation but does not protect the environment.

Supplementary Materials: The following are available online at https:/ / www.mdpi.com/2077-047 2/11/1/32/s1, Table S1: Monthly flow costs of storing one kilogram of maize in the polypropylene bag, Table S2: Monthly flow costs of storing one kilogram of maize in the PICS bags, Table S3: Monthly flow costs of storing one kilogram of maize in the Metal silo, Table S4: Monthly flow costs of storing one kilogram of maize in the Improved clay granary.

Author Contributions: Conceptualization, E.S.G., Y.P.A. and G.B.; methodology, E.S.G., Y.P.A., P.M.H., S.R.C.Z. and G.B.; software, E.S.G., P.M.H. and S.R.C.Z.; validation, E.S.G., Y.P.A., S.R.C.Z. and G.B.; formal analysis, E.S.G., P.M.H. and S.R.C.Z.; investigation, E.S.G., P.M.H. and S.R.C.Z.; resources, E.S.G.; data curation, E.S.G., Y.P.A., P.M.H. and S.R.C.Z.; writing-original draft preparation, E.S.G., P.M.H., S.R.C.Z. and G.B.; writing-review and editing, E.S.G., Y.P.A., P.M.H., S.R.C.Z. and G.B.; visualization, E.S.G., Y.P.A., P.M.H., S.R.C.Z. and G.B.; supervision, E.S.G., Y.P.A. and G.B.; project administration, E.S.G., Y.P.A. and G.B.; funding acquisition, E.S.G. All authors have read and agreed to the published version of the manuscript.

Funding: This research was funded by the Swiss Cooperation and HELVETAS Swiss Intercooperation.

Data Availability Statement: Data sharing not applicable. No new data were created or analyzed in this study. Data sharing is not applicable to this article.

Acknowledgments: We acknowledge the Swiss Cooperation and HELVETAS Swiss Intercooperation for their funding and scientific contribution to the implementation of the experimental device. We also thank the National Agricultural Research Institute of Benin (INRAB), the Food and Agricultural Technology Program (PTAA) and the experimental producers from the communes of Savalou and Boukoumbe that mobilized in the context of this research. We also thank Centre International de Recherches et de Formations en Sciences Sociales (CIRFoSS) for data collection, processing and contribution to data analysis.

Conflicts of Interest: The authors declare no conflict of interest.

\section{References}

1. MAEP. Statistiques agricoles de 2006 à 2015. 2016. Available online: https://insae.bj/images/docs/insae-statistiques / enquetesrecensements / Recensement-General-des-Entreprises/Rapport-Agriculture-RGE2.pdf (accessed on 29 September 2020).

2. Sohinto, D.; Aina, M.S. Analyse économique et financière de cinq chaînes de valeurs ajoutées (CVA) de la filière maïs au Bénin. Rapp. d'étude 2010, 76.

3. Adégbola, Y.P.; Arouna, A.; Ahoyo, N. Analyse des facteurs affectant l'adoption des greniers améliorés pour le stockage du maïs au Sud-Bénin. In Bulletin de la Recherche Agronomique du Bénin (BRAB) Numéro Spécial 2011, 8, 43-50.

4. Fandohan, P. Introduction du grenier fermé en terre au Sud Bénin pour le stockage du maïs. Rapp. Tech. Rech. INRAB-PTAA 2000, 29.

5. Maboudou, A.G.; Adégbola, P.Y.; Coulibaly, O.; Hell, K.; Amouzou, E. Factors affecting the use of improved clay store for maize storage in the central and northern Benin. In New Directions for a Diverse Planet, Proceedings of the 4th International Crop Science Congress, Brisbane, Australia, 26 September-1 October 2004; Fischer, T., Ed.; Crop Science Society of America: Madison, WI, USA, 2004.

6. Maboudou, A.G. Adoption et diffusion de technologies améliorées de stockage du maïs en milieu paysan dans le centre et le nord du Bénin. In Mémoire Pour l'obtention du Diplome D'etudes Approfondies; Unisersit2 de Lomé, Faculté des Lettres et Sciences Humaines: Lomé, Togo, 2003; 108p.

7. Adégbola, Y.P. Economic Analyses of Maize Storage Innovations in Southern Benin. Ph.D. Thesis, Wageningen University, Wageningen, The Netherlands, 2011; p. 182. 
8. Hinnou, C.L.; Aloukoutou, M.A. Stockage et conservation du maïs au Bénin: Techniques efficaces et stratégies d'adoption. Rapport d'étude 2011, 54.

9. Jones, M.S.; Alexander, C.E.; Lowenberg-Deboer, J. An Initial Investigation of the Potential for Hermetic Purdue Improved Crop Storage (PICS) Bags to Improve Incomes for Maize Producers in Sub-Saharan Africa. In Working Paper \#11-3; Department of Agricultural Economics Purdue University: West Lafayette, IN, USA, 2011; p. 44.

10. Sissinto-Gbénou, E.; Adégbola, Y.P.; Dischl, R.; Fischler, M.; Hessavi, M.P.; Ohouko, S.K.; Vodouhe, S.; Biaou, G. Efficacité des structures de stockage et de conservation du maïs au centre et au Nord du Bénin: Cas des communes de Savalou et Boukoumbé, 2018. Annales de l'Université de Parakou Series «Sciences Naturelles et Agronomie » Décembre 2018, 8, 151-167.

11. Abass, A.B.; Fischler, M.; Schneider, K.; Daudi, S.; Gaspar, A.; Rust, J.; Kabula, E.; Ndunguru, G.; Madudu, D.; Msola, D. On-farm comparison of different postharvest storage technologies in a maize farming system of Tanzania Central Corridor. J. Stored Prod. Res. 2018, 77, pp. 55-65. Available online: www.elsevier.com/locate/jspr (accessed on 29 September 2020).

12. Murdock, L.L.; Baributsa, D.; Ousmane, B.; Amadou, L.; Baoua, I.B. PICS bags for post-harvest storage of maize grain in West Africa. J. Stored Prod. Res. 2014, 58, 20-28. [CrossRef]

13. De Groote, H.; Kimenju, S.C.; Likhayo, P.; Kanampiu, F.; Tefera, T.; Hellin, J. Effectiveness of hermetic systems in controlling maize storage pests in Kenya. J. Stored Prod. Res. 2013, 53, 27-36. [CrossRef]

14. Tchegnon, P. Monographie de la commune de Boukoumbé, Ministère de la Décentralisation, Programme D’appui au Démarrage des Communes au Bénin. 2006. Available online: http://www.ancb-benin.org/pdc-sdacmonographies/ monographiescommunales / MonographiedeBoukoumbé.pdf (accessed on 29 September 2020).

15. Hodges, R.J. Post-harvest Weight Losses of Ce-real Grains in Sub-Saharan Africa. 2012. Available online: http://www.erails.net/ FARA/aphlis/aph-lis/weightlosses-reviews (accessed on 29 September 2020).

16. Adéoti, I.; Adégbola, P.Y.; Sodjinou, E.; Adéoti, R.; Sellamna, N. Processus d'adoption des technologies de stockage et de conservation du maïs au sud du Bénin. Annales de l'Université de Parakou, Bénin Série "Sciences. Naturelles et Agronomie. 2018, 137-148.

17. Pantenius, C.U. Etat des pertes dans les systèmes de stockage du mä̈s au niveau des petits paysans de la région maritime du Togo; GTZ: Hamburg, Germany, 1988; 83p.

18. Gittinger, P. Economic Analysis of Agricultural Projets, 2nd ed.; EDI series in Economic Development: Baltimore, MD, USA; London, UK, 1985.

19. Capo-Chichi, Y.J. Monographie de la Commune de Savalou, Ministère de la Décentralisation, Programme D’appui au Démarrage des Communes au Bénin. 2006. Available online: http://www.ancb-benin.org/pdc-sdacmonographies/ monographiescommunales/MonographiedeSavalou.pdf (accessed on 29 September 2020).

20. Arouna, A.; Adégbola, P.Y.; Biaou, G. Analyse des coûts de stockage et de conservation du maïs au Sud-Bénin. Bulletin de la Recherche Agronomique du Bénin, Numéro Spécial 2: Aspects économiques du stockage et de la conservation du maïs au Sud-Bénin Septembre 2011, 13-23.

21. IBM. SPSS Statistics Documentation, Anova One Factor. Available online: https://www.ibm.com/support/knowledgecenter/fr/ SSLVMB_23.0.0/spss/base/idh_onew_post.html (accessed on 29 September 2020).

22. Poudel, K.L.; Nepal, A.P.; Dhungana, B.; Sugimoto, Y.; Yamamoto, N.; Nishiwaki, A. Capital Budgeting Analysis of Organic Coffee Production in Gulmi District of Nepal. In Proceedings of the International Association of Agricultural Economists Conference, Beijing, China, 16-22 August 2009; pp. 1-13.

23. Ndegwa, M.K.; De-Groote, H.; Gitonga, Z.M.; Bruce, A.Y. Effectiveness and economics of hermetic bags for maize storage: Results of a randomized controlled trial in Kenya. Crop. Prot. 2016, 90, 17-26. [CrossRef]

24. Nduku, T.M.; De-Groote, H.; Nzuma, J.M. Comparative Analysis of Maize Storage Structures in Kenya. Presented in the 4th International Conference of the African Association of Agricultural Economists, Hammamet, Tunisia, 22-25 September 2013. 